\title{
What is 'philosophy'?
}

\section{Understandings of philosophy circulating in the literature on the teaching and learning of philosophy in schools}

\author{
Dr Lynne Bowyer \\ Dr Claire Amos \\ Dr Deborah Stevens \\ The New Zealand Centre for Science \& Citizenship \\ Correspondence: lynne@nzcsc.org
}

\begin{abstract}
This paper is based on a literature review of articles discussing the teaching and learning of philosophy in primary and secondary schools. The purpose of this review was to address two research questions:

What is philosophy?

What does philosophy do?

This paper addresses the first research question - What is philosophy? - by gathering together the various understandings of the word 'philosophy' circulating in the literature.

There are ten understandings of what philosophy is that have arisen from the literature: philosophy as a foundational concept; philosophy as thinking - a skill, a disposition, a practice; philosophy as method or process; philosophy as a tool or instrument; philosophy as a creative task; philosophy as inquiry; philosophy as search for truth; philosophy as non-dogmatic teaching and hence the emancipation of thought; philosophy as communal activity; philosophy as a way of life. These ten understandings have been consistent over time, from writing in the field in the 1970s through to the present day. Many commentators hold and work with multiple understandings of what philosophy is in their writing.
\end{abstract}




\section{Key Words}

communal activity, creativity, inquiry, multiple interpretations, thinking, way of life

\section{Introduction}

Since the 1970s there have been movements to have philosophy taught in primary and secondary schools in a number of countries. People involved with these movements have made various claims in regards to why this should be the case. The New Zealand Centre for Science and Citizenship has undertaken a literature review of articles discussing the teaching and learning of philosophy in primary and secondary schools. The purpose of this review was to address two research questions:

What is philosophy?

What does philosophy do?

In regard to the first question - What is philosophy? - the research gathered together the various understandings of the word 'philosophy' circulating in the literature.

In regard to the second question - What does philosophy do? - the research drew together claims made by commentators in respect to the work that the teaching and learning of philosophy does in the classroom.

This article was undertaken in response to expressions of need made by participants at Australasian philosophy conferences, including the New Zealand Association of Philosophy Teachers (NZAPT) and the Federation of Australasia Philosophy in Schools Association (FAPSA). Before embarking on this project we corresponded with international commentators in the field, asking if they were aware of a literature review that explored the questions 'What is philosophy and what does philosophy do?' These correspondents were unaware of any work of this kind and responded enthusiastically that a review article of this sort was needed and would be a valuable contribution to the literature.

This is the first of two articles that lays out our findings. In this article we confine ourselves to the first research question and the ten understandings of what philosophy is that have arisen from the literature concerned with the teaching and learning of 
philosophy in schools. ${ }^{1}$ These ten understandings have been consistent over time, from the early writing in the field through to the present day. Accordingly, in writing up this review we have taken a chronological approach within each of the ten interpretations.

Following a description of the research approach, this paper lays out examples of the ten interpretations and understandings circulating in the literature. The net result is one of a nuanced picture - woven of both complementary, opposing, and sometimes contradictory, interpretations. The article is not about mapping which person subscribes to which interpretation; rather it is about conveying the diversity of interpretations that present in the literature - whether these come from one person, multiple people, or are the multiple views held by one person. To that end the article is in keeping with the Greek idea of $\Lambda$ ó $\mathrm{O}$ (logos), as a gathering together and laying out, in order to provide an account that is understandable and accessible for others. Whilst this review will enable comments and further research questions to be raised by others, we have also made several comments and raised questions that point to areas of further investigation.

\section{The approach}

The literature review involved: searching ProQuest's Education Database, regarded as the principal education database; identifying websites promoting teaching philosophy in schools; listening to podcasts discussing this subject; locating media articles on the teaching and learning of philosophy in primary and secondary schools; and communication with people writing in the field. The literature search did not consult Masters and $\mathrm{PhD}$ theses, which is a limitation to this review. Further, the references offered in support of each interpretation are not exhaustive but are representative of the interpretations circulating.

The key words and phrases that were used in the search included: 'teaching philosophy in schools'; 'understandings of philosophy'; 'conceptualisations of philosophy'; 'interpretations of philosophy'; 'philosophy for children'; 'teachers' understanding of philosophy'; 'teachers role philosophy education'; 'teachers' beliefs about philosophy'; 'philosophy beliefs'; 'teacher interpretation of philosophy'; 'teaching philosophical inquiry'; 'teaching philosophy for children'; 'critical thinking';

\footnotetext{
${ }^{1}$ We have used the words 'understandings' and 'interpretations' interchangeably, recognising the hermeneutic movement involved between these two activities.
} 
'What do you mean philosophy?' Approximately 2000 texts were identified, and their abstracts read. Through this reading process, texts that spoke to the research questions were filtered out. This narrowed the research field to approximately 160 texts, which were then comprehensively read and analysed. Fifty-six texts that contained material that would meaningfully address the research questions emerged from this process. It is acknowledged that this process, which involved a judgement by us as readers in determining whether an abstract was indicative of appropriate content for in-depth analysis, is a further limitation to this review.

\title{
What is 'philosophy'?
}

Ten understandings of what philosophy is have arisen from a review of literature concerned with the teaching and learning of philosophy in schools. These are:

\author{
philosophy as a foundational concept \\ philosophy as thinking - a skill, a disposition, a practice \\ philosophy as method or process \\ philosophy as a tool or instrument \\ philosophy as a creative task \\ philosophy as inquiry \\ philosophy as search for truth \\ philosophy as non-dogmatic teaching and hence the emancipation of thought \\ philosophy as communal activity \\ philosophy as a way of life
}

\section{Philosophy as a 'foundational concept'}

Some commentators view philosophy as a concept that underpins a range of subdisciplines. In the same way that the word 'mathematics' can be said to found the subdisciplines of algebra, geometry, number, and statistics, 'philosophy' is viewed by 
some as the concept that is foundational to 'metaphysics, ethics, epistemology ... logic' (Sleeper 1978, p. 237). According to Sleeper (1978), each of the sub-disciplines of philosophy are 'implicit ... in every subject matter, at every level' (p. 237). Robinson (1995) broadens the foundations of philosophy, stating that 'all subjects have a foundational dimension that is philosophical' (p. 7). Similarly, Fitzsimons (2014) remarks that philosophy can be understood as 'the discipline that best prepares us to think in terms of the other disciplines' (p. 1238). Poulton (2014) reiterates Sleeper's list, whilst also adding 'ontology' to that list (p. 1240).

McCall and Weijers (2017) embrace philosophy as foundational to every aspect of collective human life, forming the basis from which we build our thoughts about things, make judgements and subsequently act. For McCall and Weijers, enabling people to see and understand underlying philosophical assumptions is therefore empowering for people (p. 83).

Developing Robinson's (1995) and Fitzsimons' (2014) ideas, Hand (2018) explicitly talks about the philosophical dimension of a range of subject areas, including 'moral philosophy, political philosophy and philosophy of religion' (p. 19). Splitter (2019) concurs that philosophy is a concept that founds a range of sub-disciplines, adjusting Poulton's list of 'subdisciplines' of philosophy, so that the 'familiar classification' includes: 'metaphysics, ethics, logic, epistemology, aesthetics, philosophy of science, political and social philosophy' (pp. 80-81).

In the literature there seems to be several ways in which the idea of philosophy as foundational is being used. For some commentators it is the bedrock from which various silos arise (metaphysics, epistemology etc.). For others it is the underlying structure that makes possible investigation into various disciplines such as 'religion', 'science', ' politics', and so forth. For some, philosophy is foundational in the sense that it underpins our ability to think and act. The latter understanding of 'foundational' (McCall and Weijers) sees philosophy as integral to our human way of being and links to an understanding of philosophy as a way of life, which is expanded later in this article. In contrast, the former understandings see philosophy as an abstract, specialised field that is positioned over and above our humanity. Exploring the implications of these different understandings and what kind of conversations/dialogue about life that they make possible is warranted. 


\section{Philosophy as thinking-a skill, a disposition, a practice}

Philosophy is talked about by some authors as 'thinking', which is conceived of as a skill, a disposition or a practice that can be continually honed and improved. As a skill, philosophy is concerned with the 'development of critical reasoning skills through questioning and dialogue' (Topping \& Trickey 2007, p. 74 italics added). For some authors, philosophy as a thinking skill is a concept that results from the coming together of discrete ways of thinking and discrete types of skills. Hannam and Echeverria (2009) say that 'thinking skills take place through the interaction between four key "elements"' (p. 91). These elements are: '(1) critical thinking; (2) creative thinking; (3) collaborative thinking; and (4) caring thinking (Ibid.). There are also four 'categories of skills', namely: '(1) good reasoning skills; (2) investigatory skills; conceptual skills; and (4) translation skills'.

Daniel and Auriac (2011) appear to make distinct 'philosophy' and 'critical thinking' but argue that they are based on the same criteria in that 'both philosophy and critical thinking propose logical reasoning, critical dialogue and methodical doubt' (p. 420). Lam (2012) notes that the 'New Jersey Test of Reasoning Skills (NJTRS) was developed by Virginia Shipman to evaluate the Philosophy for Children programme' (p. 188), linking the concept of philosophy to forms of reasoning that are understood to be amenable to standardised testing and measuring.

Within the literature, the concept of reasoning is compartmentalised into various 'forms of reasoning', 'including, analogical reasoning, inductive reasoning, syllogistic reasoning, detecting underlying assumptions, discerning causal relationships, identifying "good" reasons, and recognising dubious authority' (Lam 2012, p. 188).

Benade (2014) argues that it is through philosophy that the disposition of critical thinking can be honed, and such thinking 'has elements of creativity, impartiality, reflectivity and fortitude' (p. 1254). Benade continues that 'the disposition of critical thinking will mean that the individual takes nothing for granted and constantly questions and enquires' (p. 1254). Cam (2014) notes that 'philosophy is a discipline with a particular focus on thinking. It involves thinkers in the cognitive surveillance of their own thought. It is a reflective practice, in the sense that it involves not only careful thinking about some subject matter, but thinking about that thinking, in an effort to guide and improve it' (p. 1207, italics added). In his 2018 paper, Cam seems to speak of this practice as 'higher-order thinking' (p. 62). 
Knight and Collins (2014) also speak about philosophy as thinking, which can be actively improved, noting that philosophy has 'a rigour and depth characteristic of good thinking' (p. 1291). For Weber and Wolf (2017), this rigour and depth manifests itself as a hermeneutic process that continuously scrapes away the layers of assumptions that adhere to our concepts, values and beliefs (p. 80). Acknowledging that it is 'questions' that lie at the heart of a rich and thoughtful dialogue, Weber and Wolf also point to the importance of 'questioning the question' in order to plumb the depths of complexity, something that only a philosophical disposition can achieve ( $p$. 74). Hand (2018) describes these dispositions as 'curiosity, attentiveness, rigour, openmindedness, tenacity and intellectual courage' - thinking practices which can be developed and improved through philosophical engagement (pp. 4-5).

Winstanley (2018) argues that the 'expression and development' of thinking skills are particularly likely to emerge through philosophical teaching and are 'less likely to emerge in other subjects' (p. 121). Cam (2018) agrees, and remarks that poor thinking 'is a deficiency that philosophy-and perhaps only philosophy-can remedy' (p. 69).

Whereas Hannam and Echeverria (2009) talk in terms of philosophy being a skill that requires the coming together of discrete ways of thinking-critical thinking; creative thinking; collaborative thinking; caring thinking-Splitter (2019), referring to Philosophy for Children (P4C), discusses how the practice of philosophy creates the opportunity for modelling different thinking and speaking styles. These styles are: 'the hard-nosed logical thinker; the creative or imaginative thinker; the empathetic, caring thinker; the cautious, uncertain thinker; even the rigid, dogmatic or rulegoverned thinker' (pp. 80-81). Splitter notes that some of these may be combined in a single character.

For many commentators, philosophy is seen as thinking par excellence. Such thinking incorporates a number of 'styles' and is intimately related to questioning. It is something that can be continually improved through specific forms of practice, and - for some - it is amenable to being tested and measured. For the most part, 'thinking' here is conceived of as an intellectual pursuit, not grounded in a particular context, and unrelated to action. For a number of commentators, such 'thinking' is also premised on a particular rationalist conception of 'being human'; a creature that is 'under development' towards a particular kind of end-product. It is important to consider the value judgements implicit in this, especially in relation to the child in the classroom. Is thinking-as conceived of in this manner-nothing more than an instrumental practice that, in being developed, will grant our children (if they are 
'successful') a place in a pre-conceived technocratic and bureaucratic world? What does talking in terms of a 'philosophical disposition' make possible in contrast to talking in terms of 'philosophy as a skill' or as a 'style of thinking'?

\section{Philosophy as method or process}

For others, philosophy seems to be understood primarily as a process of logic - a method or approach that can be taught, practiced and applied. Sleeper (1978) notes that the philosophical classroom will be a place for discovering and putting to use the logical methods of problem-solving, of identifying the most successful ways of reaching conclusions and arriving at evaluative judgments' (p.239). Sprod (1995) speaks about how philosophy 'involves algorithms, heuristics, attitudes and traits ... [it] is a judicious blend' (p. 24).

Daniel and Auriac (2011) discuss how Lipman takes a systematic approach to critical thinking, describing four categories of thinking skill that develop: conceptualisation; reasoning; generalisations; research. This approach 'revolves around three fundamental criteria: 1) use of particular criteria (to evaluate the terms of statements); 2) self-correction (to engage in an active search for one's own mistakes; 3) sensitivity to context (to recognise that different contexts require different applications of rules and principles)' (p. 420).

Taking the notion of philosophy as a method or systematic process, Massa (2012) talks about 'applying the Lipman-method' when discussing the teaching of philosophy ( $\mathrm{p}$. 771, emphasis added). Similarly, Poulton (2014) speaks about 'philosophy programmes that [have] been delivered in primary classrooms' (p. 1238, emphasis added). Cam (2018) argues that 'philosophy's contribution, in short, is not so much a matter of content as it is of method' (p. 69). For Hand (2018), this method involves tackling 'particular kinds of problem and develop[ing] particular forms of argument and analysis to solve them' (p. 7).

Winstanley (2018) speaks of how 'abstraction is part of philosophical method' (p. 121, emphasis added). Worley (2018) agrees, remarking that philosophy is a systematic process concerned with 'concepts and thinking about concepts in the abstract' (p. 84).

Hobbs (2018) speaks of how the approach of Greek philosophy is a 'supremely useful pedagogic resource' (p. 24, emphasis added), whilst Worley (2018) remarks that 'doing 
dialectical philosophy is more than just a model for thinking, but also a pedagogy for how to practise thinking well' (p. 82, emphasis added).

For commentators who view philosophy as method or process, philosophy is seen as a 'thing' that can be 'applied' in a procedural, systematic way, or 'delivered' to students in a packaged or programmatic form. The language used conveys that philosophy - as a 'thing' - can take only certain forms, and those who want to engage in 'philosophy' must come to understand and work with these predetermined forms in order for their contributions to count as philosophy. Questions that arise include whether understanding philosophy as process or method legitimises a dominant form of rationality? Does it silence other voices, or discount ideas that come about in ways other than the pre-conceived process? Does understanding philosophy as process or method marginalise thoughts and ideas that are conveyed in different ways from the standard form of argument? Does philosophy understood as process or method become dogmatic? Is this approach to philosophy based on a modern conception of scientific inquiry, so that what can be 'known' and the procedures for such 'knowing' are established in advance? If so, what are the inherent limitations and problems with this?

\section{Philosophy as a tool or instrument}

As distinct from process or method, some commentators understand philosophy to be a tool or instrument to be employed for a particular task. For Sprod (1995), 'a good thinker' that is, one who has 'done' philosophy, 'knows which "tools" from her "toolkit" to use and when' (p. 24). Biesta (2011) refers to philosophy as something that can be 'deployed' to 'work upon individuals so that they can develop and/or acquire certain qualities, capacities and skills' (p. 310). Daniel and Auriac (2011) refer to critical thinking as 'a tool for countering unconsidered actions and thoughts' (p. 420). Thompson and Lašič (2014) speak of the "'thinking tools" of philosophy' (p. 1232). Vansieleghem (2014) - referring to Lipman's Philosophy for Children - notes that, 'only philosophy in its active form could provide the instruments that enable children to think for themselves and make their own decisions' (p. 1301, emphasis added). Hobbs (2018) echoes this, arguing that 'the acquisition of ... logical tools is vital if children are going to learn how to reason, analyse and ask good questions' (p. 25). Of these instruments and 'tools', Cam (2018) notes that 'philosophy has an ample supply' (p. 72). Prior and Wilks (2019) note that 'philosophical inquiry provides an excellent tool for broadening students' perceptions. experience and learning' (p. 189). 
In a similar way that those conveying the idea of philosophy as method or process write about 'applying' a particular approach, or 'delivering' philosophy in the classroom, those who view philosophy as a tool also see it as a 'thing', or a set of 'things' to be implemented or 'deployed' in a discrete way. The emphasis is put on the instrumental use of philosophy, 'deployed' to work on individuals so that they can develop/acquire a way of being that is deemed to be of value. Questions that can be raised for consideration about this interpretation of philosophy include: Does philosophy as a tool consolidate the idea that philosophy is an abstract, specialised field, not accessible to everyone?

\section{Philosophy as a creative task}

Philosophy is also understood to be a creative task. Sharp (1995) notes that the word philosophy is - amongst a number of other things - about 'aesthetic inquiry' and the work of 'engaging children in exploring problematic issues that involve the relationships between artistic creation, aesthetic appreciation and aesthetic criticism' (p. 45). Lipman (1995) echoes this interpretation, remarking that creative thinking 'involves discovering as well as inventing, is comprised of all inquiry processes, artistic and scientific, and includes perceptual thinking as a form of discovery' (p. 61). For Lipman, there is only the discipline of philosophy that 'is capable of fostering the normative application of this broad spectrum of thinking modes [of which creativity is one]' (p. 61). Daniel and Auriac (2011) note that this creative task can take the form of 'inventing, associating, suggesting alternatives, making analogies, [and] formulating hypotheses' (p. 418). Cam (2014) remarks that, as with all other creative tasks, philosophy 'is a case of learning by doing' (p. 1204).

Philosophy as a creative task is not about regurgitating 'facts' or finding the 'correct' answer to a problem. Over time, commentators have broadened the notion of creativity to include the free-ranging of thought, as - to paraphrase Daniel and Auriac-we invent, make associations, come up with alternatives and seek ways forward. Lipman points to the normativity of this work, recognising that thinking manifests itself not as 'knowledge' but as the ability to discern right from wrong, and that what we bring into being as we think has real-world affects. It is therefore important to consider: Does institutionalising philosophy as a programmatic way of engaging stifle creativity? Does the way in which $\mathrm{P} 4 \mathrm{C}$ has been 'applied' as an instrumental 'method' by some practitioners in the classroom undermine and sit at 
odds with Lipman's original insights about what philosophy is and its significance in the classroom?

\section{Philosophy as inquiry}

Referring to Lipman's Philosophy for Children (P4C) model, Sleeper (1978) believes it evident 'that every subject matter can be taught philosophically'. Here philosophy is not understood as a subject comprised chiefly of the "competing doctrines of the historically important philosophers, together with the methods they employed' that may be taught to students, but rather, 'that philosophy is a discipline of critical examination and inquiry' (p. 237). As a discipline of inquiry, philosophy is concerned with interrogational questions (p. 237). Proedfriedt (1988) speaks about philosophy as being concerned with 'inquir[ing] into the validity of truth claims' (p. 297), enabling people to move away 'from voicing unsupported opinions' (p. 295).

In justifying philosophy as inquiry, Ennis (1993) states that such inquiry involves being 'open-minded' and 'judging the credibility of sources, identifying conclusions, reasons and hypotheses, appreciating the quality of argument, developing and defending points of view, asking relevant clarifying questions, searching for reasons, drawing conclusions that are viable and credible' (p. 180).

Sharp (1995, p. 45) speaks in terms of five kinds of inquiry that constitute philosophy:

Ethical inquiry: engaging children in examination of issues that deal with the role of moral values and norms in human conduct;

Aesthetic inquiry: engaging children in the exploration of issues that involve artistic creation, and the relationship between artistic creation and aesthetic appreciation and aesthetic criticism;

Metaphysical inquiry: engaging children in achieving 'greater generality in their understanding of the world and its way of working';

Logical inquiry: Engaging children in thinking about thinking, including reflecting on the 'rules of inquiry';

Epistemological inquiry: Engaging children in questions such as 'What counts for true?' and 'What is the relationship between truth and meaning?' 
Sharp (1995) also talks about the role of inquiry for examining concepts - for example, the concepts of 'justice, personhood, freedom, democracy, good, truth, friendship, self and identity' (p. 46), noting that philosophy encourages learners to 'ferret out for themselves the underlying assumptions [of] such concepts' (p. 46). Like Sharp, Vansieleghem (2014) speaks about 'ferreting out [the] underlying assumptions and implications' of our 'explanations and arguments' (p. 41). This enables 'inquiry into fundamental human problems and issues, where all the general conceptions that animate society come under scrutiny' (Cam 2014, p. 1205).

Regardless of the specific characteristics of the inquiry undertaken however, Millett and Tapper (2014) remark that inquiry provides 'beautiful insights into the rich thinking that children are capable of when they talk and listen to each other in pursuit of conceptual clarity' (p. 1216). For Burgh (2018), philosophy's greatest educational force is as an 'inquiry pedagogy'. Through inquiry 'students improve their cognitive abilities, increasing not only their knowledge of the learning areas, but also the connections made between all aspects of the curriculum' (p. 43). Echoing Millett and Tapper (2014), Hand (2018) notes that the pursuit of conceptual clarity is a good starting place for philosophical inquiry, and such inquiry can become more sophisticated over time (pp. 4-5).

Like Thompson and Lašič (2014), who discuss a range of interrogational questions that philosophy can cover to do its work (p. 1230), Hobbs (2018) remarks that philosophy's interrogational questions 'positively invite' interpretation and debate, opening up the possibility of rich conversations (p. 25). The conversations that ensue from such questions are good conversations, in that they 'pertain to deep ideas, and seek to clarify concepts that may be debated, or arguments that may not be entirely settled' (D’Olimpio \& Peterson 2018, p. 105).

Prior and Wilks (2019) note that philosophical inquiry engages with and responds to the world in which we live, enabling the examination of beliefs and values, and facilitating self-reflections, which can be a transformative process (p. 185 \& p. 194). Thinking about philosophy as inquiry, Cam (2014) and Prior and Wilks (2019) explicitly ground such inquiry in the world in which we live, exploring and critically engaging with fundamental human problems and issues. For other commentators, inquiry remains at an abstract level, devoid of a lived context. For example, for Sharp (1995), the world is divided into 'compartments' in order for the process of inquiry to get underway. Others see inquiry as a means for getting 'conceptual clarity', again in 
a decontextualised way. But if philosophy is to be meaningful for young people might it become more so if inquiry is based in the world in which they are anchored?

\section{Philosophy as search for truth}

For other writers, philosophy is concerned with ascertaining 'truth'. Sleeper (1978) states that 'a philosophical lesson must be concerned with truth and how it is achieved' (p. 238). Lipman, Sharp and Oscanyan (1980) state that 'each belief must be subjected to the tests of logic and experience' (p. 133). Daniel and Auriac (2011) note that-for some-philosophy is about 'establish[ing] true reasons on which various beliefs are based' (p. 419). Biesta (2011) states: 'one thing that is remarkable ... is the strong orientation [of philosophy] towards knowledge and truth' (p. 307). Cam (2014) states that philosophy has 'a genuine concern for truth and clarity' (p. 1204). Hand (2018) argues that philosophy - as disciplined inquiry cultivated through sustained participation-equips children to think clearly and reason carefully. It is therefore 'conducive to the assessment of evidence and the estimation of truth' (p. 5).

The nature of 'truth' is also discussed. For Sleeper (1978), truth is concerned with 'the discovery of the grounds of values, of right and wrong' (p. 238). Such concern for truth and how it is achieved requires 'sorting out the logical and epistemological status of the great variety of kinds of truth claims' (p. 238). Sleeper argues that this 'should be a major focus of attention in the philosophical classroom' (p. 238), while later, Vansieleghem (2014) talks in terms of 'know[ing] the causes of ideas - the conditions under which they are thought' (p. 1302).

Other commentators challenge the idea that philosophy can be a search for a 'definitive truth'. Biesta (2011) points out that 'there are parts of the philosophical tradition that have the potential to make us hesitate, to put us on the spot, to put our normal ways of being and doing into question ... a quality of philosophy ... [that] has an orientation towards not-knowing,' rather than 'knowing for sure' (p. 317).

There is a pervasive idea in the literature that philosophy is a search for truth, which can be ascertained through clear thinking and a process of reasoning that aims to sort through truth-claims in order to provide 'knowledge'. This seems to be an abstract, decontextualised process. Questions that need to be asked include: What kind of 'knowledge' and 'truth' is philosophy so conceived oriented towards? Whose truth is privileged through this process? What prejudices impact on truth-seeking? How does 
unquestioning loyalty to a regime, another person, or an institution impact on the framing of truth? How does the interplay of experience, history, culture, family, emotions, education and so forth, shape truth for us?

Biesta's idea that philosophy should make us 'hesitate' and 'put our normal ways of being and doing into question' seems to point to the need to ground truth in the lived world of particular people at a particular time (italics added). It also suggests that noone has the whole truth about a situation, so there can be no search for 'absolute' truth. Discerning truth certainly involves questioning, time, commitment and tenacity. To establish truth requires open engagement with one another, so that truth can be tested in a trustworthy community, requiring testimony to be remembered. Truth can be revealed to us when we are open to and grapple with a range of perspectives, but it is never beyond doubt. For Biesta, this makes philosophy emancipatory.

\section{Philosophy as non-dogmatic teaching, and hence the emancipation of thought}

Philosophy is also understood as 'non-dogmatic teaching', so that 'indoctrination is antithetical to philosophical inquiry ... and is out of place in the philosophical classroom' (Sleeper 1978, p. 238). Philosophy means remaining open and being comfortable with a 'lack of closure' (Sleeper 1978).

As non-dogmatic teaching, Fisher (1995) notes that philosophy is a way to 'combat prejudice, encourage tolerance, and ... help children feel confident about their capacity to think for themselves' (p. 89). As non-dogmatic and emancipatory, philosophy will 'liberate the child from the possibility of being an unaware "pawn" in the technological system of the written, printed and spoken word. Philosophy allows children to recognise when anyone in authority is using an unexamined philosophical concept and to question [the] assumptions that are being made' (Sharp 1995, p. 46).

To be emancipatory, philosophy must continually put our habitual ways of being and doing into question, so that we remain 'in the position of the child as the one whose seeing, thinking and doing is not yet "filled" with knowledge, categories and ways of speaking with others' (Biesta 2011, pp. 317-318). In-keeping with philosophy as creativity, philosophy requires imagination and is well-suited to children who 'cover much the same ground that philosophers have', in that they 'generally turn to the 
world with fresh thoughts, ideas, free and open eyes, imagination and permanent curiosity' (Martin 2011, p. 1).

Daniel and Auriac (2011) reiterate this idea of 'freshness', so that to remain nondogmatic and emancipatory, philosophy must not 'stagnate into mere conversation' because, 'in doing so, [it will] fall within the scope of negative realism, where all perspectives are accepted and acceptable, where assertions are neither evaluated nor prioritized' (p. 430) - that is, it will no longer 'be philosophy'.

It is suggested that philosophy can only be non-dogmatic and emancipatory if it continually subjects itself to critical scrutiny, because an emphasis on a particular method - such as a "'rational epistemological" approach, or the "Lipman method" can be dogmatic itself, excluding other ways of thinking and attending to an issue' (Hannam \& Echeverria 2009, p. 13).

In contrast to Hannam and Echeverria, Vansieleghem (2014) remarks that 'the use of P4C is related to the appeal not to be obedient to dogmatism' (p. 1302). She argues that 'increasingly, the practice of philosophy for children' is about 'creating challenging environments ... symbolic spaces, contexts of zones where different meanings are circulating [and] where individual thinking is put under critique' (2014, p.1035). Vansieleghem goes on to remark that 'to know the causes of ideas-the conditions under which they are thought -is to liberate ourselves from intellectual rigidity and to bestow upon ourselves that power of choosing among and acting upon alternatives ... [this] is the source of intellectual freedom' (2014, p. 1302). Philosophy thereby prevents people from unquestioningly 'submit[ing] to the imperatives of a social, political, cultural or religious nature' (2014, p. 1301).

Doddington (2014) notes that philosophy requires 'a natural tendency to "wonder"' and, if our teaching of children is 'to be truly educational, any form of response [to them] should not close down the enquiry with an answer, but should preserve and inspire further capacity to wonder' (p. 1265). In short, to be emancipatory philosophy must 'entertain possibilities' (p. 1266).

As non-dogmatic thought, philosophy 'represents a structural intervention', that alters habitual ways of thinking, speaking and doing (Stewart 2014, p. 1274). Fitzsimons (2014) remarks that such an intervention is an opening, that would bring 'fresh and sometimes startling winds blowing through the classrooms of the nation' (p. 1285, referencing Greene 2000, p. 134). Fitzsimons adds, that if 'teachers are concerned to promote education as the development of independent thought beyond 
the realm of instrumental utility, then philosophy is a vital, and potentially critical, engagement with power, with the way schools' function, and more generally with society and its government' (p. 1276).

Michaud and Valitalo (2017) also address how the emancipatory nature of philosophy challenges how schools function, pointing to philosophy's ability to undermine structures of power through its recognition of human fallibility and the uncertainties we face (p. 31). In the classroom setting, neither teacher nor student can ever claim to have the 'ultimate' or 'complete' answer, so there can be no claim to authority (p. 31). Winstanley (2018) also notes how 'philosophy disrupts the common classroom experience', which is an experience of being expected to provide 'right' answers to questions, which are verified by the teacher (p. 123).

However, Reed-Sandoval and Sykes (2017) draw attention to the enormous challenges of establishing a truly emancipatory classroom, which is more than disestablishing traditional authoritarian structures of teacher-student relationships. Reed-Sandoval and Sykes point out that there are young people in our classrooms from a range of cultures/ethnicities 'who are positioned such that their lived experiences and philosophical questions are socially under-valued and unrecognised, and thus underrepresented' in classroom situations (p. 220). Talking in relation to the way that the P4C programme operates, Reed-Sandoval and Sykes state that if young people are marginalised in this way, they 'may struggle to articulate the questions that are most meaningful to them' (p. 220). Furthermore, if their interests are not represented in the discussions taking place, those discussions will not bear any relevance to them, which may leave them feeling silenced. The ways in which teachers hear and interpret the contributions of students on the margins may further distance them from the discussion (p. 220). Chetty and Suissa (2017) concur, pointing out that P4C can work to replicate the same harmful structures that it states it wishes to challenge, as it can reflect, re-inscribe and re-enforce social meanings and racial privilege through its work (p. 16).

In contrast, Glaser and Gregory (2017) argue that P4C is well-placed to facilitate philosophy's emancipatory task, whilst acknowledging that this can be a dauntingly complex task 'in a pluralistic, media-saturated world in which we participate in multiple communities of meaning making that sometimes vie for primacy' (p. 180). Glaser et al. argue that P4C provides opportunities for a 'multitude of interchanges' through which young people can grapple with, 'appropriate, accommodate and transcend cultural meanings' (p. 180), all of which are transformative and life-shaping. 
Hobbs (2018) - like Reed-Sandoval and Sykes - recognises that for philosophy to be truly emancipatory it must enable young people to see that 'there are different ways of living, being and thinking than those immediately on offer in their local postcode' (pp. 30-31).

Through our own work with young people from a range of cultural backgrounds, in which we philosophically explore aspects of the world that we are currently inhabiting, we, along with our students as co-constructors of our exploration, experience philosophy as emancipatory. By holding open a space for young people to question practices that affect themselves or others, they are empowered to think about the world, and how they have been shaped by - and in turn come to shape-that world. Thus, thinking readily translates into action. It is a practice that is essentially communal as, for thought to be genuinely emancipatory, it necessarily holds open a space for the ideas, perspectives and hence the lives of others. Becoming aware of one another's ways of being and ways of knowing opens up possibilities that have previously been concealed from each another. Thinking and hence action can be dangerous activities. Therefore, what is crucial to philosophy as emancipatory is a recognition of our shared humanity, situated in a realm that we share with other forms of life, which must bound the possibilities that are open to us. Questions in regard to this that need to be explored include: What structures, institutions and forms of practice prevent or inhibit the emancipatory task of philosophy? Do the dominant understandings of ourselves and our place in the world marginalise some people and some ways of living and being and skew the boundaries of emancipatory thought? If so, what needs to change, and how?

\section{Philosophy as a communal activity}

Commentators construing philosophy as a communal activity argue that it encompasses both speech and action, aimed at improving how we live together.

As a communal activity, philosophy as an 'art of dialogue may have begun with Socrates himself' (Proedfriedt 1988, p. 296). Almond and Hill (1991) speak about an 'outward facing philosophy' that helps us to find 'solutions to the problems of political and social life' (p. 1). As such, philosophy can be 'an influential force in the public arena' (p. 6). As a communal activity, philosophy is about working together to overcome 'prejudice and narrowmindedness' - whether 'academic, social, personal, professional, religious, racial, national, [or] ideological' (Paul 1992, p. 4). As a 
communal endeavour, philosophy is crucial for being 'sensitive to' and 'tackling the great number of problems challenging the world today' (UNESCO 2006, pp. 3-4; UNESCO 2007). It is 'essential in developing a democratic and peaceful culture' (UNESCO 2006, p. 14; UNESCO 2007).

Topping and Trickey (2007) argue that philosophy is a communal activity that helps us to 'construct a deeper understanding (or better solution) than would be possible individually' (p. 76). Through the to-and-fro of dialogue, 'the ability to think well' is gradually acquired, as participants are 'challenged and assisted to be clearer, more consistent, more imaginative, etc', and are consequently 'made accountable to [their] community of peers' (Gregory 2007, p. 162).

Daniel and Auriac (2011) note that philosophy 'implies an open dialogue within a community of peers and a dialectical relationship between reflection and action', where dialogue is understood as 'an active and critical method of communication' that 'aims to solve a common problem' (p. 422). They note that such dialogue 'differs from conversation in that it calls upon complex cognitive and social skills, these being constant attention to the words of another and a surpassing of oneself in the search for questioning that holds meaning, valid justifications, appropriate arguments, constructive criticisms, etc.' (p. 422).

A sense of philosophy as a communal activity is shared by Cam (2014), who writes about the work of 'thinking together' (p. 1205), and that in such work we 'subject our reasons to each other's judgement, or try to follow an argument where it leads' ( $p$. 1207). In following one another's style of thinking, 'we are like detectives whose clues are the experiences, inferences, judgements and other intellectual considerations that each thinker brings' to the situation at hand (p. 1208). The importance of 'thinking together' is also noted by Costa-Carvalho and Mendonca (2017). Referring to the P4C programme, Costa-Carvalho and Mendonca note that learning to think is a communal activity that seeks to nourish 'a reasonable community'. They argue that an 'individual cannot become fully reasonable by thinking and acting on his own', and that participation in the communal activity of thinking-together 'is a necessary part of being reasonable' (p. 128). For Burgh (2018), philosophy as a communal activity 'reflects democracy as a way of life'. To this end, philosophy is not only about developing students' capacities for critical thinking, but also requires the development of 'creative thinking, ethical behaviour, and personal and social capabilities' (p. 43). 
In a philosophical classroom, the communal nature of philosophy requires that everyone involved must not only track their own thinking, they must also become capable of tracking the thinking of all the other group members (Worley 2018, p. 84). By engaging with and tracking philosophical dialogue young people develop confidence in articulating their own reasoned ideas (p. 78). Through engaging in philosophical dialogue, we 'can come to appreciate that a good philosopher knows how to listen as well as talk' (Hobbs 2018, p. 25).

Glaser and Bass (2019) also note a range of benefits that arise when working with philosophy as communal activity. It is through thinking together that we learn to play close attention to what is being explored. Working communally, we are exposed to multiple perspectives, and we can pick up and run with-or respectfully challengeone another's ideas, as we learn to pay attention to ways of reasoning (p. 29).

Golding (2019), remarks that unlike the approach of traditional western philosophy, which is 'intellectually combative', with people 'attacking' and 'defending' established positions, the communal nature of P4C enables 'thinking together' to explore philosophical issues. This makes philosophy accessible and relevant for all ages, enriching everyone's thinking and cultivating conceptual clarity (p. 131). Reflecting on his early experiences with philosophy as a communal activity, Splitter (Splitter \& Glasser 2019) states that what happens in that shared, collaborative philosophical space 'is so significant on intellectual, social, ethical and affective/personal grounds' (p. 12). Philosophy as a communal activity cultivates respectful dialogue-even if we disagree we must disagree respectfully. It is therefore crucial that students treat one another as persons, because 'ideas originate in people who have feelings as well as opinions' (pp. 10-11). The communal nature of philosophy also binds those who are engaged with a philosophical issue to those who have been thinking about such issues for thousands of years. Young people are joining this dialogue 'on their own terms, but also on equal terms with one another' (Splitter 2019, p. 84).

For commentators who view philosophy as a communal activity, reason becomes grounded in our 'thinking together'. There is a tension and a danger here, depending on how the 'community' is established and facilitated. The space can become an echochamber, where certain ideas are reinforced and others rendered invisible, or it can become an emancipatory space in which our own horizons of insight are nuanced and broadened as other ways of being-other lives-come into view. 
Although viewing philosophy as a communal activity, many commentators do not ground such philosophy in communal issues, which means that thinking together can still be an abstract task. In contrast, Almond and Hill (1991) acknowledge that if such philosophy is 'outward facing' we can attend to issues in 'political and social life'. Grounding such thinking in local, pertinent issues makes the communal engagement meaningful for those involved.

As a communal activity, the cooperative nature of thinking together is emphasised, which is a move away from forms of philosophy that are more combative in nature. As Splitter has noted, this allows and requires those involved to respect one another's humanity and also to respect those who have gone before and who have contributed to the depth and breadth of human thought. This also shows that ideas are not ahistorical, and are part of a temporal narrative, linking us to a past. This helps us to understand where we have been, and who we have become-and when held in an emancipatory space-enables us to consider what kind of people we want to become as we move into our future.

\section{Philosophy as a way of life}

Philosophy is understood by some authors as being about the way in which we conduct ourselves and our lives. For example, Robinson (1995) writes that 'we are all philosophers. Every time we give a reason for our opinions, reflect on whether some reason is a better reason than some other, wonder about the various meanings of some word, we are doing philosophy' (p. 5). For Robinson, philosophy is essentiallycrucially-concerned with 'how we treat others' (p. 9).

For Costello (1995), philosophy must become a way of life so that children come to 'cultivate those reflective habits which are crucial to their future lives as citizens' ( $p$. 107). Fields (1995) agrees, arguing that philosophy is key in 'educating pupils for responsible citizenship' (p. 17). Gazzard (1996) understands philosophy to be a thoughtful activity that 'generates in its students the desire to know how to live a more meaningful life', (p. 11, in Daniel \& Auriac 2011, p. 418).

Rondhuis and Van der Leeuw (2000) write that 'philosophy is more than analysing and speculating, it has to do with the conduct of life itself, and so presupposes a redress to reflect on and clarify experience. This implies not only cognitive skills, but attitudes as well' (p. 30). 
Philosophy is also understood by some authors to be concerned with the generation of meaning and, in particular, meaning that enables us to live well together as creatures who must continually work to make sense of themselves and the things they do. With this in mind, Doddington (2014) remarks that 'doing philosophy through discussion can contribute to authentic language experiences ... through which 'both personal and cultural identity can be forged' (p. 1265). She notes that, crucial to these discussions and this understanding of philosophy, is a spirit of 'openness, wholeheartedness, engagement and responsibility' (p. 1265). Doddington observes that open, wholehearted philosophical discussions enable participants to 'create meaning for themselves'. Such meaning-making happens through both listening to others and becoming more aware of one's own thoughts and ideas as they are discussed. Active philosophical engagement not only serves to articulate the emotional and reflective life, but also constitutes it (p. 1264).

Philosophy as a way of life is key to raising citizens who are able to embrace their role as 'critic and conscience of society' (Fitzsimons 2014, p. 1283). Echoing earlier remarks from Costello, Cam (2014) also argues that philosophy as a way of life must 'be part of the regular fare throughout the school years' (p. 1206), as it can significantly affect both the way people think and the character of their concerns.

As a way of life, philosophy can be understood as constitutive to our human way of being, in that it enables someone to become conscious of oneself, the world, and one's place within it: 'for the child who is philosophising, critical thinking is ... no longer [only] about getting access to "scholastic skills" such as logical thinking, but about becoming conscious on one's life processes, emotions and abilities and relating oneself in an active, conducive manner towards this process' (Vansieleghem 2014, p. 1304). Karikio (2016) notes that 'any topic brought up is a question of human dignity and responsibility' (p. 111).

Haynes and Murris (2017) uphold Doddington's (2014) ideas regarding the creation and weaving together of meaning through philosophical engagement, and how this constitutes lived experience. Through any philosophical engagement people individually and collectively 'bring memories, emotions, associations and experiences to bear on the occasion' (p. 177). Any texts being used elicit and weave with participants' own narratives. Meaning arises from the interplay of all these dynamic elements; it is a unique, unrepeatable moment which allows new depths of experience to be explored and opens up new possibilities (p. 177). 
For Hobbs (2018), philosophy as a way of life means becoming conscious of the world, oneself, and what sort of person one aspires to be. This requires us to consider the structure, shape and narrative of a well-lived life. By so doing 'young people can start to get an understanding of what a flourishing life or a stunted or warped life might look like, and what kind of intellectual, emotional and physical faculties need to be developed, and what intellectual and moral virtues fostered, in order to help a person live the former and avoid the latter' (p. 30-31).

Reflecting on their early work of teaching philosophy in schools, Splitter and Glaser (2019) comment that the success of philosophical practice cannot be measured by,

the number of workshops conducted, books published, or schools engaged but rather, by the measure to which children's place in their communities has been transformed, the extent to which the tradition of philosophy as a form of life centred around the construction of meaning is recognised and drawn upon as a rich resource for children's own meaning-making, and the extent to which there is space for children to think, reason, engage and be heard. (pp. 21-22, emphasis added)

If philosophy is a living act, it is necessarily an individual and a communal way of being. Teachers play a pivotal role in nurturing this way of being, and therefore their integrity as people and their praxis is of central concern. The ability and the need we have to make sense of ourselves and the things we do, along with the ways in which thinking can transform our ways of living and being, has to be placed first and foremost in our education of young people. Recognising the normativity of philosophy as a way of life means that we must ensure education provides a safe place for exploring ways of living and being so that, to paraphrase Hobbs (2018), we can thoughtfully guide young people towards a life worth living, upholding human dignity and the responsibilities that come with that.

If philosophy is essential to our human way of being, how can we change education from a system that is driven by economic and bureaucratic considerations, focused on the production of a particular kind of individual that will fit the prevailing job market and contibute to the economy, to one which nurtures people to question, challenge and act to change current practices that are not conducive to living well together? If philosophy is a way of being/living it must be thoroughly woven into all our educational interactions. Education plays a pivotal role in shaping how young people come to think and act. To have merit, education must provide opportunities for young people to identify and explore the issues and structures that negatively affect 
individuals and communities, and act to challenge and change those situations so that all people are able to live well together.

As people, we may survive without philosophy, but without it we will not flourish in the way that is possible for us. Commentators who view philosophy as a way of life argue for the need to incorporate this in education from the earliest years so that it becomes an integral part of our human sensibilities and therefore of our individual, communal, cultural and political life.

\section{In summary}

This review gathers together and lays out the various understanding of what philosophy is that are circulating in the literature, in order to provide an account that is understandable and accessible for others. As authors, we have made several comments and posed questions that point to areas of further investigation. These are not exhaustive and we welcome others to comment and raise further research questions.

It is apparent from the literature concerned with teaching philosophy in schools that philosophy is a complex and contested concept which plays an essential role in human life. Regardless of what aspect of philosophy has become the focus of a commentator's writing - whether that be philosophy as inquiry, philosophy as a communal activity, philosophy as a creative task, or philosophy as emancipatory - philosophy embraces forms of thinking that are regarded as important for people. Commentators who view philosophy as more than just an academic pursuit explicitly extend the idea that ways of thinking must also entail ways of acting, and hence, ways of being. This is clearly articulated by authors who argue for philosophy as a way of life.

Areas of tension exist in the literature in regard to some interpretations of philosophy. This is most evident in discussions which conceive philosophy as a search for truth, and the discussions in regard to philosophy as method or process. The idea that philosophy can give us definitive truths is challenged by those who view philosophy as non-dogmatic and emancipatory. Similarly, it is argued that philosophy as nondogmatic and emancipatory must be free from particular methods or processes which might lock down or constrain thinking in a particular way.

Some writers are against the idea of thinking about philosophy in terms of being foundational to a myriad of sub-disciplines, each of which seeks to acquire 
'knowledge' in its area. Instead, they highlight philosophy's social, cultural and political significance, and the way that it can illuminate an issue, and deepen and broaden our understanding of it. In this role, philosophy is integral to critiquing, creating and informing the world and our place within it.

For some commentators, philosophy is a competitive discipline, concerned with 'defending' knowledge, and reaching a 'successful conclusion', through the acquisition of a set of scholastic skills. For others, philosophy is a communal, cooperative endeavour, concerned with shared exploration and sense making, in a way that constitutes one's very being. As a communal, cooperative endeavour, philosophy is not about developing a command of the literature written by historical or contemporary philosophers and challenging their ideas; instead, philosophy is an organic, dialectical practice connecting thought and action in a way that constitutes who we are and what we do.

As it is a complex concept, those writing in the area of teaching and learning philosophy in schools are often working with multiple understandings of philosophy at the same time. However, the nature of these understandings also differs according to how they are woven together. For instance, some writers discussing philosophy as inquiry whilst at the same time holding a foundational notion of philosophy, view the nature of inquiry differently from those who take philosophy to be a communal activity. The former are concerned with questions that can be siloed in some way, such as 'metaphysical questions', 'epistemological questions'. The aim is to work towards and defend a definitive answer. In contrast, inquiry as a communal activity is concerned with developing a sensitivity to, and raising questions about, practices which impact negatively on individuals and communities. The aim is to work towards better ways of living together.

It is apparent from the example above that how people conceive of philosophy will map onto the work that they claim the teaching and learning of philosophy does. In part two of this research we engage with the literature on teaching philosophy in schools in order to lay out the claims and the support for the work that philosophy does. 


\section{References}

Almond, B \& Hill, D (1991) Applied philosophy: Morals and metaphysics in the contemporary debate. London, Routledge.

Benade, L (2014) Developing democratic dispositions and enabling crap detection: Claims for classroom philosophy with special reference to Western Australia and New Zealand. Educational Philosophy and Theory, 46(11), pp. 1243-1257.

Biesta, G (2011) Philosophy, exposure, and children: How to resist the instrumentalisation of philosophy in education. Journal of Philosophy of Education, 45(2), pp. 305-319.

Burgh, G (2018) The need for philosophy in promoting democracy: A case for philosophy in the curriculum. Journal of Philosophy in Schools, 5(1), pp. 38-58.

Cam, P (2014) Philosophy for children, values education and the inquiring society. Educational Philosophy and Theory, 46(11), pp. 1203-1211.

Cam, P (2018) The generic argument for teaching philosophy. Journal of Philosophy in Schools, 5(1), pp. 59-75.

Chetty, D \& Suissa, J (2017) 'No go areas': Racism and discomfort in the community of inquiry. In MR Gregory, J Haynes \& K Murris (eds) The Routledge international handbook of Philosophy for Children. London, Routledge Taylor and Francis Group, pp. 11-18.

Costa-Carvalho, M \& Mendonca, D (2017) Thinking as a community: Reasonableness and emotions. In MR Gregory, J Haynes \& K Murris (eds) The Routledge international handbook of Philosophy for Children. London, Routledge Taylor and Francis Group, pp. 127-134.

Costello, P. J. M. (1995) Education, citizenship and critical thinking. Early Child Development and Care, 107(1), pp. 105-114.

D'Olimpio, L \& Peterson, A (2018) The ethics of narrative art: Philosophy in schools, compassion and learning from stories. Journal of Philosophy in Schools, 5(1), pp. 92-110.

Daniel, M-F \& Auriac, E (2011) Philosophy, critical thinking and Philosophy for Children. Educational Philosophy and Theory, 43(5), pp. 415-435. 
Doddington, C (2001) Entitled to speak: Talk in the classroom. Studies in Philosophy and Education, 20(3), pp. 267-274.

Doddington, C (2014) Philosophy, art or pedagogy? How should children experience education? Educational Philosophy and Theory, 46(11), pp. 1258-1269.

Ennis, RH (1993) Critical thinking assessment. Theory into Practice, 32(3), pp. 179-186.

Fields, JI (1995) Sleepers awake: The current debate using philosophy with young children (citizenship, philosophy and reasoning: citizens of the twenty-first century). Early Child Development and Care, 107(1), pp. 17-21.

Fisher, R (1995) Stories for thinking - the Philosophy in Primary Schools (PIPS) project. Early Child Development and Care, 107(1), pp. 85-95.

Fitzsimons, P (2014) School and the limits of philosophy. Educational Philosophy and Theory, 46(11), pp. 1276-1289.

Gazzard, A (1996) Philosophy for Children and the discipline of philosophy. Thinking, 12(4), pp. 9-16.

Glaser, J \& Bass, A (2019) Getting started: The early use of the IAPC curriculum. In G Burgh \& S Thornton (eds) Philosophical inquiry with children: The development of an inquiring society in Australia. London, Routledge Taylor and Francis Group. pp. 23-31.

Glaser, J \& Gregory, MR (2017) Education, identity construction and cultural renewal: The case of philosophical inquiry with Jewish Bible. In MR Gregory, J Haynes \& K Murris (eds) The Routledge international handbook of Philosophy for Children. London, Routledge Taylor and Francis Group, pp. 180-188.

Golding, C (2019) Connecting concepts and developing thinking classrooms. In G Burgh \& S Thornton (eds) Philosophical inquiry with children: The development of an inquiring society in Australia. London, Routledge Taylor and Francis Group, pp. 131-142.

Greene, M (2000) The dialectic of freedom. In R Reed \& T Johnson (eds) Philosophical documents in education. New York, NY, Addison-Wesley Longman, pp. 123-141.

Gregory, MR (2007) Normative dialogue types in philosophy for children. Gifted Education International, 22, pp. 160-171. 
Hand, M (2018) On the distinctive educational value of philosophy. Journal of Philosophy in Schools, 5(1), pp. 4-19.

Hannam, P \& Echeverria, E (2009) Philosophy with teenagers: Nurturing a moral imagination for the $21^{\text {st }}$ century. London, Continuum.

Haynes, J \& Murris, K (2017) Readings and readers of texts in Philosophy for Children. In MR Gregory, J Haynes \& K Murris (eds) The Routledge international handbook of Philosophy for Children. London, New York, Routledge Taylor and Francis Group, pp. 171-178.

Hobbs, A (2018) Philosophy and the good life. Journal of Philosophy in Schools, 5(1), pp. 20-37.

Karikio, S (2016) The new responsibility and challenge of education: The current and prospective situation of Philosophy for Children. Practice and Theory in Systems of Education, 11(2), pp. 105-117.

Knight, S \& Collins, C (2014) Opening teachers' minds to philosophy: The crucial role of teacher education. Educational Philosophy and Theory, 46(11), pp. 1290-1299.

Lam, C-M (2012) Continuing Lipman's and Sharp's pioneering work on Philosophy for Children: Using Harry to foster critical thinking in Hong Kong students. Educational Research and Evaluation, 18(2), pp. 187-203.

Lipman, M (1995) Moral education higher-order thinking and philosophy for children. Early Child Development and Care, 107(1), pp. 61-70.

Lipman, M (2003) Thinking in education. Cambridge, Cambridge University Press.

Lipman, M, Sharp, AM \& Oscanyan, FS (1980) Philosophy in the classroom. Philadelphia, PA, Temple University Press.

Martin, D (2011) Matthew Lipman, philosopher and educator, dies at 87. The New York Times, January 14, p. 1.

Massa, S (2012) Philosophy for Children in an Italian primary classroom. Proceedings of the 8th International Conference on Education. Samos Island Greece, 05-07 July 2012, pp. 765-771. 
McCall, CC \& Weijers, E (2017) Back to basics: A philosophical analysis of philosophy in Philosophy with Children. In MR Gregory, J Haynes \& K Murris (eds) The Routledge international handbook of Philosophy for Children. London, Routledge Taylor and Francis Group, pp. 83-92.

Michaud, O \& Valitalo, R (2017) Authority, democracy and philosophy: the nature and role of authority in a community of philosophical inquiry. In MR Gregory, J Haynes \& K Murris (eds), The Routledge international handbook of Philosophy for Children. London, Routledge Taylor and Francis Group, pp. 27-33.

Millett, S \& Tapper, A (2014) Philosophy and ethics in Western Australian secondary schools. Educational Philosophy and Theory, 46(11), pp. 1212-1224.

Paul, R (1992) Critical thinking: What, why, and how. New Directions for Community Colleges, 77(1), pp. 3-24.

Poulton, J (2014) Identifying a K-10 developmental framework for teaching philosophy. Educational Philosophy and Theory, 46(11), pp. 1238-1242.

Prior, S \& Wilks, S (2019) Philosophy in public and other educational spaces. In G Burgh \& S Thornton (eds) Philosophical inquiry with children: The development of an inquiring society in Australia. London, Routledge Taylor and Francis Group, pp. 185-198.

Proedfriedt, WA (1988) Teaching philosophy and teaching philosophically. The Clearing House, 58(7), pp. 294-297.

Reed-Sandoval, A \& Sykes, AC (2017) Who talks? Who listens? Taking 'positionality' seriously in Philosophy for Children. In MR Gregory, J Haynes \& K Murris (eds) The Routledge international handbook of Philosophy for Children. London, New York, Routledge Taylor and Francis Group, pp. 219-225.

Robinson, W (1995) Why 'Philosophy for Children'? Early Child Development and Care, 107(1), pp. 5-15.

Rondhuis, T \& Van der Leeuw, K (2000) Performance and progress in philosophy: An attempt at operationalisation of criteria. Teaching Philosophy, 23(1), pp. 23-42.

Sharp, AM (1995) Philosophy for Children and the development of ethical values. Early Child Development and Care, 107(1), pp. 45-55. 
Sleeper, R (1978) Pre-college philosophy. The Social Studies, 69(6), pp. 236-243.

Splitter, LJ (2019) Memo to Harry Stottlemeier and friends: You are not wanted here! Reflections on the idea of a philosophy curriculum in Australia. In G Burgh \& S Thornton (eds) Philosophical inquiry with Children: The development of an inquiring society in Australia. London, Routledge Taylor and Francis Group, pp. 73-86.

Splitter, LJ \& Glaser, J (2019) Philosophy for Children comes to Australia. In G Burgh \& S Thornton (eds) Philosophical inquiry with children: The development of an inquiring society in Australia. London, Routledge Taylor and Francis Group, pp. 9-22.

Sprod, T (1995) Cognitive development, philosophy and children's literature. Early Child Development and Care, 107(1). pp. 23-33.

Stewart, G (2014) Kaupapa Māori, philosophy and schools. Educational Philosophy and Theory, 46(11), pp. 1270-1275.

Thompson, G \& Lašič, T (2014) That's not for our kids: The strange death of philosophy and ethics in a low socioeconomic secondary school. Educational Philosophy and Theory, 46(11), pp. 1225-1237.

Topping, KJ \& Trickey, S (2007) Impact of philosophical enquiry on school students' interactive behaviour. Thinking Skills and Creativity, 2, pp. 73-84.

UNESCO (2007) Philosophy: A school of freedom-Teaching philosophy and learning to philosophize: Status and prospects. Paris, United Nations Educational, Scientific, and Cultural Organisation - Social and Human Sciences Sector.

UNESCO (2006) Intersectoral strategy on philosophy. Paris, United Nations Educational, Scientific, and Cultural Organisation - Social and Human Sciences Sector.

Vansieleghem, N (2014) What is Philosophy for Children? From an educational experiment to experimental education. Educational Philosophy and Theory, 46(11), pp. 1300-1310.

Weber, B \& Wolf, A (2017) Questioning the question: A hermeneutical perspective on the 'art of questioning' in a community of philosophical inquiry. In MR Gregory, J Haynes \& K Murris (eds) The Routledge international handbook of 
Philosophy for Children. London, Routledge Taylor and Francis Group, pp. 7482.

Winstanley, C (2018) Deep thinking and high ceilings: Using philosophy to challenge 'more able' pupils. Journal of Philosophy in Schools, 5(1), pp. 111-133.

Worley, P (2018) Plato, metacognition and philosophy in schools. Journal of Philosophy in Schools, 5(1), pp. 76-91. 